\title{
Jlamprang Batik Motive : Representation of the Natural and Cultural Environment of Pekalongan City
}

\author{
Siti Maziyah ${ }^{1 *}$, Alamsyah Alamsyah ${ }^{1}$, and Dina Tri Lestari ${ }^{2}$ \\ ${ }^{1}$ Lecture of Department History, Faculty of Humanities, Diponegoro University, Semarang- Indonesia \\ ${ }^{2}$ Student of Department History, Faculty of Humanities, Diponegoro University, Semarang- Indonesia
}

\begin{abstract}
The purpose of this study was to determine the environment and culture of Pekalongan City through the jlamprang batik motif as one of the icons of Pekalongan batik motif. The problem of this research is related to the causes of the emergence of jlamprang batik motifs in Pekalongan as well as the environment and culture that shape this culture. The method used in this study is a qualitative research method, beginning with a literature study, followed by in-depth interviews with craftsmen, batik makers, and observers of Pekalongan batik, as well as direct observations at the production site. The results showed that Pekalongan is a port city that allows multicultural trade to occur as well as a city that has a batik creative industry. The cultural environment of Pekalongan was shaped by Arab Muslim traders, among others, indicated by the jlamprang motif as a flower-shaped and brightly colored batik motif.
\end{abstract}

\section{Introduction}

The living environment is the unity of space with all objects, forces, conditions, and living things, including humans and their behavior, which affect nature itself, the continuity of life, and the welfare of humans and other living creatures. The environment is not something that is always related to exact sciences, because the environment is a unit that includes various living things and all components around them, which include physical, chemical, socio-cultural components, and other components. In the socio-cultural component, this element is in the form of the social and cultural environment that surrounds humans. The things that are targeted are value systems, ideas, and beliefs in determining human behavior as social beings [1,2]. Thus the natural environment and the cultural environment can influence humans in processing their minds to produce culture. According to Koentjaraningrat [3], there are three kinds of culture produced by humans, namely ideas, activities, and material cultural results. One type of material culture product is batik, which is the main study of this research.

\footnotetext{
* Corresponding author: mazy muiz@yahoo.com
} 
Pekalongan Pekalongan is one of the cities on the North Coast of Java, which is known as one of the batik-producing areas [4]. Until now, the life of the people of Pekalongan has a lot to do with work related to batik, both in the process of making batik and selling the products produced [5]. Therefore, it is not surprising that in Pekalongan, there are also centres for selling batik products such as the Sentono Wholesale Market, Kauman Batik Village, and the Batik Museum, so that Pekalongan deserves to be called the City of Batik $[5,6,7]$. In addition, with regard to the majority of religions adhered to by the Pekalongan community, namely Islam, and there are many Islamic boarding schools as a means of Islamic religious education, Pekalongan is also referred to as the City of Santri [4]. This cultural blend of batik and santri makes Pekalongan a unique city and has been widely studied by various parties [4, $5,6,7,8,9,10,12,13,14]$.

Based on previous research, it can be examined the history of the development of Pekalongan City as a port city that has residents from various foreign ethnicities and has a batik culture with each ethnic background. In that city, there is a batik developed by the Javanese, the Chinese, and the Dutch $[11,12,13,14,16]$. In addition, based on preliminary research that has been done, it can be seen that Pekalongan has a distinctive batik motif that it produces, namely the jlamprang batik motif $[15,16,17,18,19]$. What is the jlamprang batik motif like? Why has the jlamprang motif become an icon of Pekalongan City? What kind of natural and cultural environment can influence the formation of the cultural product? Based on the research problem, the purpose of this study is to determine the natural environment and cultural environment of Pekalongan City, which influences the creation of the jlamprang batik motif to become an icon of Pekalongan City and its visual form.

\section{Research Methods}

This research is qualitative research and uses literature study to trace the creation of the jlamprang batik motif in Pekalongan. The jlamprang batik motif as an icon of Pekalongan City can be traced through the results of previous studies contained in articles [9, $10,18,19]$ and published books $[15,16,17,20,21]$, as for tracing the traces of the creation of the jlamprang batik motif, first traced the natural environment and the cultural environment found in Pekalongan City by using a map showing the location of Pekalongan City and previous research literature that discussed the historical problems of Pekalongan City $[11,17]$. Based on the history of Pekalongan City, it can be seen that Pekalongan was a port city and a trading city that became a subordinate area of the Islamic Mataram Kingdom and later became the VOC's territory. Through literature on trade in Southeast Asia [22], it can be seen that during the VOC's rule, traders had difficulty getting supplies of trading commodities from foreign traders, especially patola cloth as one of the luxury fabrics that were in demand by Javanese and Eastern Indonesians [23, 24; 25, 26, 27]. The existence of these difficulties has led to the growth of creativity from traders to create cloth motifs similar to patola motifs with techniques that have been mastered by local residents. Based on further research, religious background and ethnic origins turned out to be influential in the selection of patola motifs and colours used. 


\section{Results and Discussion}

\subsection{Pekalongan Natural Environment as a Port City}

Pekalongan is one of the regencies located on the North Coast of Central Java. Geographically, the district is bordered by the Java Sea and Pekalongan City in the North, Batang Regency in the East, Banjarnegara Regency in the South, and Pemalang Regency in the West [see Figure 1]. If you look closely, there is Pekalongan Regency and Pekalongan City. Pekalongan Regency has a wider area than Pekalongan City [see figure 2]. Besides that, most of the Pekalongan Regency is a mountainous area in the southern part of the Dieng Plateau series. Meanwhile, Pekalongan City is a sedimentation area formed on the North Coast of Java-like other coastal cities [19], for example, Semarang [28].

The clues of Pekalongan City as an ancient port city cannot be clearly known when it started. The Loji River is said to be one of the links between the coastal areas and the hinterlands in Pekalongan [17,28]. The earliest indications related to Pekalongan's role as a port city began to appear in the 16th century along with Zheng, He's expeditions that stopped at Pekalongan, and then the Chinese settled in Pekalongan along the Loji River. As for the Arab traders, many lived in villages side by side with the indigenous population $[17,19]$

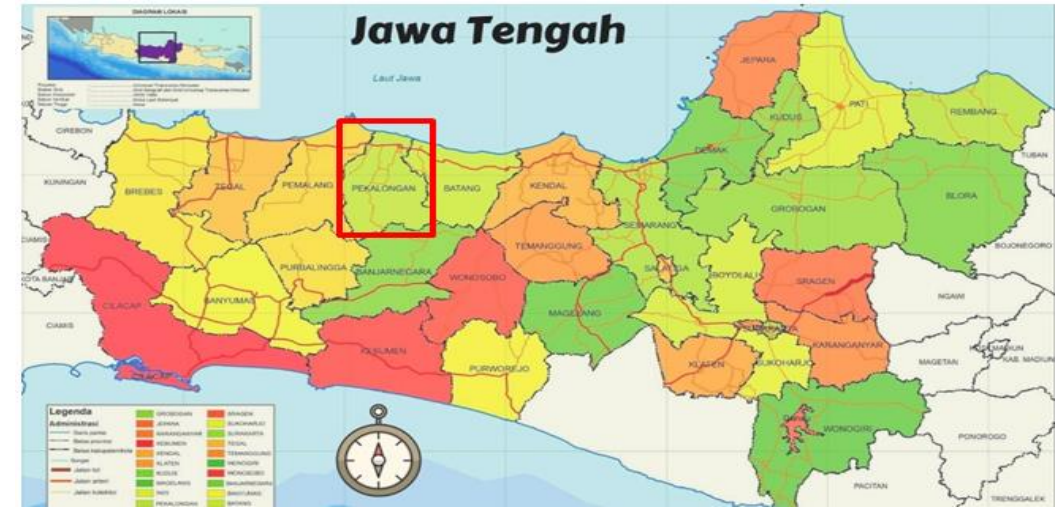

Fig. 1. Pekalongan Regency in Central Java [19].

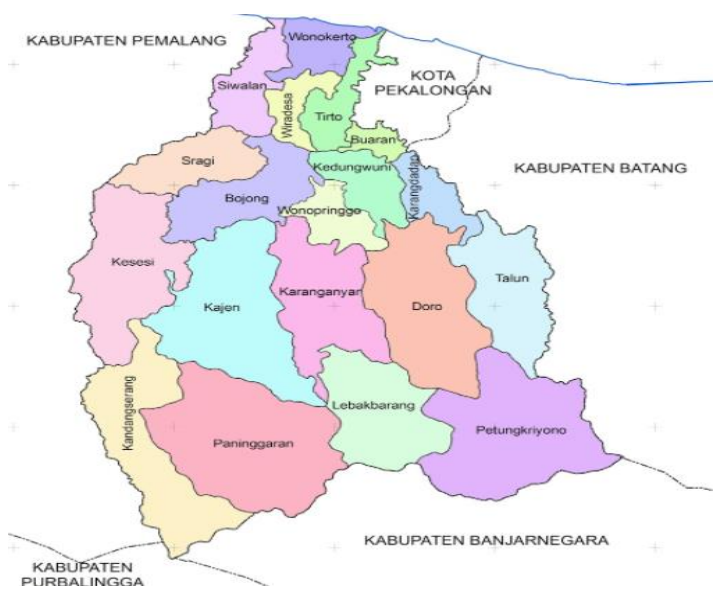

Fig. 2. Pekalongan Regency and Pekalongan City [20]. 
According to Djoko Suryo [11], the development of Pekalongan and other coastal areas experienced an increase in the early 17 th century along with the expansion of the Islamic Mataram Kingdom under Sultan Agung (1613-1645). Pekalongan City increasingly developed into a coastal city when the North Coast of Java fell into the hands of the VOC from the rule of the Mataram Kingdom in 1743. Under the VOC's rule, Pekalongan City rose to become a port city and a trading city for export commodities in the Pekalongan region, such as rice, sugar, and indigo. On the other hand, imported goods from outside the Pekalongan region and its surroundings. Since then, the Port of Pekalongan has become the responsibility of a porter who is generally controlled by the Chinese. In the middle of the 18th century, more and more immigrants from China came to Pekalongan to trade and then settled down [11].

Pekalongan Port was officially opened on May 31, 1859, with the status of a medium port and started operating the next day. This port experienced progress until the 20th century. In 1924 this port turned into a small port due to a decline in exports. After independence, Pekalongan Harbor received less attention and was more used for fishing activities. Until then, in 1974, this port by the government was changed to a Fishing Port [29].

\subsection{The Four Ethnic Cultures of Pekalongan City}

Pekalongan City, as a port city has multicultural and multiethnic $[7,9,7,10,11,12,14$, $17,19]$. Pekalongan City is one of the coastal cities in Java; of course, the majority of the population is Javanese. In subchapter 3.1. It is mentioned that Pekalongan City at the beginning of the 17th century became the territory of the Islamic Mataram Kingdom as a coastal area. By being a coastal area for the Islamic Mataram Kingdom, Pekalongan City has a culture similar to the cultural centre of the Islamic Mataram Kingdom in Yogyakarta, among others, seen in the batik culture as an effort to prepare clothes for the family $[4,16$, 20]. The batik culture then became increasingly developed in Pekalongan City and even to Pekalongan Regency, so that it became a cultural identity for the people of Pekalongan City and Pekalongan Regency [5, 8, 10, 11, 17].

Besides the Javanese people, Pekalongan City as a port city is also visited by other ethnic groups. In subchapter 3.1. it is stated that in the 16th century, there were already Chinese settlements along the Loji River. Furthermore, the Chinese traders were increasingly crowded and settled in Pekalongan in the mid-18th century. The existence of settlers from China apparently helped develop batik in Pekalongan, so that Pekalongan batik is not only an expression of the Javanese people but is also related to Chinese cultural expressions $[9,16$, 17, 29].

In subchapter 3.1. it is also said that in the mid-18th century, Pekalongan City fell to the VOC. This indirectly provides information that starting in the middle of the 18th century, the Dutch began to influence the culture of Pekalongan City more intensively. Thus, it is not surprising that the existence of Dutch batik in Pekalongan City was around the middle of the 19 th century $[12,16,17,30]$.

Furthermore, there is still one foreign ethnic that has an influence on the culture in Pekalongan City. Its existence is also estimated to have existed in Pekalongan City in the 16th century, and they lived mingling with Javanese society in general [17]. They mostly live in Kauman Village [14]. The Arab ethnicity in Pekalongan City is the focus of this research.

The existence of these four different ethnic groups in Pekalongan City is what causes the characteristics of batik in Pekalongan City to be different from other places. The hallmark of coastal batik is the natural depiction of motifs and the use of bright colours [12, 17, 19, 20, $21,29]$. 


\subsection{Jlamprang Batik Motifs: Cultural Adaptation of Arab Traders for Pekalongan City}

Apart from being a port city, Pekalongan City is also automatically one of the trading cities on the North Coast of Java. Various trading commodities from Pekalongan City as well as imported goods came brought by traders who arrived in Pekalongan. One of the trade commodities that are needed by the community is cloth. Patola is a type of luxury woven fabric from India which is in great demand in Java [27]. The existence of this cloth is quite interesting in Java and in the archipelago because, in addition to having beautiful motifs and attractive colours, it turns out that the philosophical value of this cloth motif also affects the mindset of the Javanese and in the archipelago so that they also cult and sacred the cloth. One of the people's beliefs about the function of the cloth is that it can be used to relieve pain if someone who is sick is covered with a woven cloth with a patola motif [24]. The following is a picture of various patterns of patola weaving originating from India.
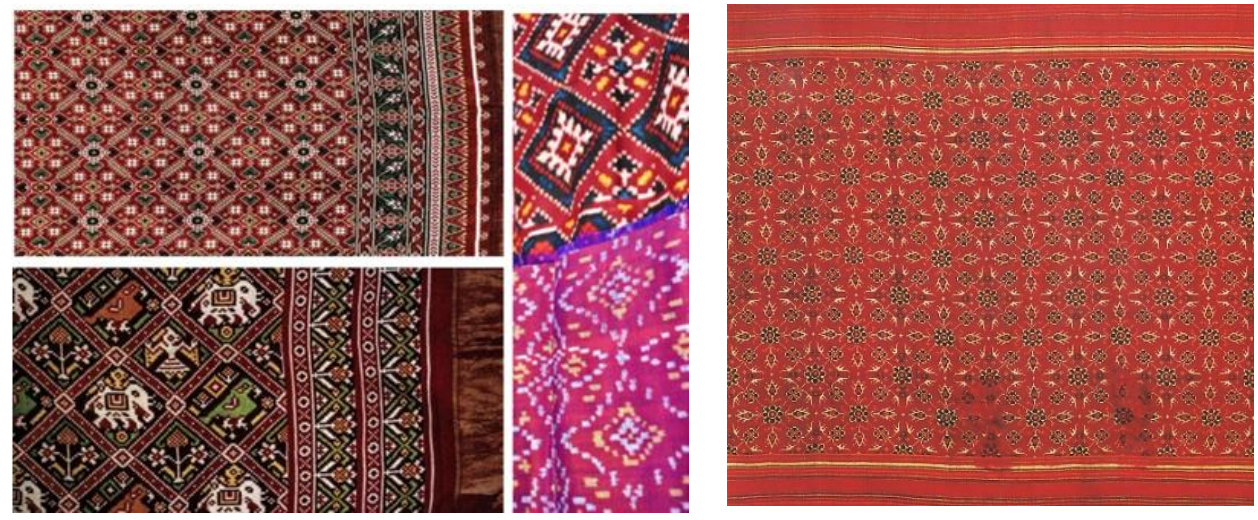

Fig. 3. Various Types of Patola Motifs from India [16, 25].

The circulation of this luxury cloth trade has been going on for centuries in Java [25, 27 , 32]. This trade was disrupted due to the trade monopoly imposed by the VOC in the 18th century. All trade commodities other than those brought by the Dutch were prohibited from entering at various ports, including cloth [30]. This turned out to be quite disruptive to the supply of patola motif woven fabrics that are in demand by many people. This business opportunity was later captured by Arab traders who settled in Pekalongan. With the batik skills possessed by the people of Pekalongan, the Arab traders transformed the patola weaving motif into a batik motif. The work of batik patola pattern was initially carried out by Pekalongan batik makers along Jalan Perang, the road used by Dutch soldiers for war training. Therefore, the new batik motif was called the Jlamprang batik motif [15, 20].

Not all patola motifs are liked by the people of Java and the Archipelago. The motifs they like are motifs in the form of repeated geometric images which represent various types of flowers $[15,16,20,22,27,32]$. This was very advantageous for Muslim Arab traders who believed that there was a prohibition against depicting living creatures [33]. Therefore, later this Arab Muslim trader developed the patola weaving motif into the jlamprang batik motif as one of the batik motifs in the form of flowers, as a motif that does not conflict with the teachings of his religion. The following is a picture of the transformation of the patola weaving motif into the jlamprang batik motif. 


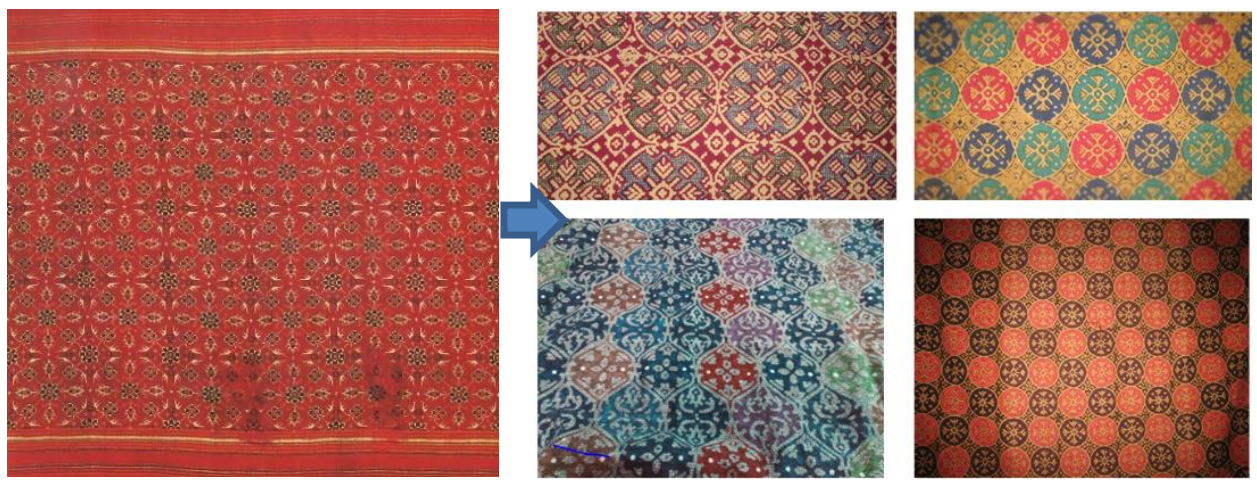

Fig. 4. Patola Weaving Motif Becomes Jlamprang Batik Motif Motif [13, 33].

\section{Conclusion}

The results showed that Pekalongan is a port city that allows multicultural trade to occur as well as a city that has a batik creative industry due to its intensive cultural contact with the Islamic Mataram Kingdom. The natural cultural environment as a port city causes the people of Pekalongan City to become a society that is always open and easy to adapt to foreign nations. One of the nations that make up the culture of Pekalongan City is Arab Muslim traders. With the ability to adapt and innovate to overcome the scarcity of commodity supply of patola motif woven fabric from India, the Arab merchant poured patola weaving motifs by making batik according to the local capabilities of the people of Pekalongan City. The choice of motifs is adjusted to the beliefs held, which are not depicting living beings. Therefore, a motif in the form of flowers was chosen, as a motif that did not conflict with the teachings of his religion. The batik motif was given the name jlamprang as a reminder that the work was originally carried out along Jalan War in Pekalongan City. Thus, it can be concluded that the natural environment and the cultural environment can affect the results of human culture so that Arab traders in Pekalongan can innovate patola weaving motifs into jlamprang batik motifs. In the world of batik, the type of batik developed by traders is called sudagaran batik.

\section{References}

1. Susanto, S. Seni Kerajinan Batik Indonesia. Yogyakarta: Balai Penelitian Batik dan Kerajinan, Lembaga Penelitian dan Pendidikan Industri, Departemen Perindustrian Republik Indonesia (1973)

2. Suksmasakti H, A., B. Hayati, "Strategi Pengembangan Obyek Wisata Batik Kota Pekalongan", Diponegoro Journal of Economics, Vol. 1, No. 1, (2012)

3. Ainul, Kh. "Manajemen Bisnis Kaum Santri (Study Kasus Pada Pengusaha Batik di Kampung Batik Kelurahan Buaran Kecamatan Pekalongan Selatan Kota Pekalongan)". Skripsi. Semarang: Fakultas Ekonomi dan Bisnis Islam Universitas Islam Negeri Walisongo (2014)

4. Pratiwi, E. "Perkembangan Batik Pekalongan Tahun 1950 -1970", Skripsi, Semarang: Jurusan Sejarah Fakultas Ilmu Sosial Universitas Negri Semarang (2013)

5. Salma, I R. “Corak Etnik dan Dinamika Batik Pekalongan “, Dinamika Kerajinan dan Batik, Vol. 30, No. 2, hlm. 85-97 (2013). 
6. Purnomo, M. A. J. "Batik Encim Pekalongan, Kehalusan Batik Gaya Cina Di Pesisir Jawa", Pendhapa: Journal of Interior Design, Art and Culture, Vol. 1, No. 1. (2010)

7. Hayati, Ch. "Pekalongan Sebagai Kota Batik 1950-2007”, Lensa: Kajian Kebahasaan, Kesusasteraan, dan Budaya, Vol. 2, No. 1, (2012)

8. Wasino, dan E. S. Hartatik, Dari Industri Gula Hingga Batik Pekalongan: Sejarah Sosial Ekonomi Pantai Utara Jawa pada Masa Kolonial Belanda, Yogyakarta: Magnum Pustaka Utama (2017)

9. Nurhayati, F. "Batik Pekalongan Pada Masa Kolonial (1830-19450)", Skripsi, Purwokerto: Fakultas Keguruan dan Ilmu Pendidikan Universitas Muhammadiyah Purwokerto (2018)

10. Karima, H. N. "Pola Wilayah Industri Batik di Kota Pekalongan", Skripsi, Jakarta: Fakultas Matematika dan Ilmu Pengetahuan Alam Departemen Geografi Universitas Indonesia (2010)

11. Astianisti, D. "Relasi Mayoritas-Minoritas Antara Etnis Jawa, China, Arab (Studi Kasus Di Kelurahan Kauman Kota Pekalongan)", Skripsi, Semarang: Jurusan Sosiologi Dan Antropologi Fakultas Ilmu Sosial Universitas Negeri Semarang (2015)

12. Djoemena, N. S. Ungkapan Sehelai Batik: Its Mystery and Meaning. Cetakan ke-2, Jakarta: Djambatan (1990)

13. Doellah, S. Batik: Pengaruh Zaman dan Lingkungan. Surakarta: Danar Hadi (2002)

14. Asa, K. Batik Pekalongan dalam Lintasan Sejarah, Yogyakarta: Cahaya Timur Offset (2006)

15. Nurullah, B. "Integratet Marketing Communication (Studi Kasus Pada Batik Jlamprang Pekalongan)". Skripsi. Surakarta: Universitas Muhammadiyah Surakarta (2020)

16. Suryani. "Pengaruh Budaya Asing Terhadap Perkembangan Batik Pekalongan". CORAK Jurnal Seni Kriya, Vol. 2, No.1, hlm. 71-82 (2013)

17. "Pengertian Lingkungan Hidup, Unsur, Manfaat dan Upaya Pelestariannya ". https://lingkunganhidup.co/ pengertian-lingkungan-hidup/ diakses tgl 19 Mei 2020

18. Nagtegaal, L. "Riding the Ducth Tiger: The Dutch East Indies Company and the Northeast Coast of Java 1680-1743", Verhandelingen van het Koninklijk Instituut voor Taal-, Land- and Volkenkunde, Vol. 171, Leiden: KITLV Press (1996)

19. "Peta Jawa Tengah Kengkap Nama http://carilokasijalan.blogspot.com/2017/08/peta-jawa-tengah-lengkap-namakabupaten-kota.html diunduh tgl 1-6-2018

20. Cendanisari, T.K., "Peta Administrasi Kabupaten Pekalongan". https://3.bp.blogspot.com/-ubt38kvw-CA/WGYFHhqdecI/AAAAAAAACoM/puFP-

NE7gpoN3zLHz8E5P u-

CyC4EUTLgCLcB/s1600/peta\%2Bkabupaten\%2Bpekalongan.jpg (2012)

21. Indrajaya, D. W. "Sejarah Hari Ini (1 Juni 1859) - Titik Awal Perniagaan Pelabuhan Pekalongan". https:/www.goodnewsfromindonesia.id/2020/06/01/sejarah-hari-ini-1juni-1859-titik-awal-perniagaan-pelabuhan-pekalongan diakses tgl 2 Juni 2021

22. Roemah Bhinneka Surabaya. "Batik: Warisan Budaya Peranakan”. Nggosipin Tionghoa Yuk! Pertemuan ke-29. https://youtu.be/hXi01U_5124 (2021)

23. Ishwara, H., L.R. S. Yahya, dan X. Moeis. Batik Pesisir Pusaka Indonesia: Koleksi Hartono Sumarsono. Cetakan Pertama. Jakarta: Kepustakaan Populer Gramedia (2011)

24. Heringa, R. dan H. C. Veldhuisen, Fabric of Enchantment, Batik from the North Coast of Java, Singapure: Los Angeles County Museum of Art (1997) 
25. Veldhuisen, H. C. Batik Belanda 1840-1940, Pengaruh Belanda pada Batik dari Jawa Sejarah dan Kisah di Sekitarnya, Penerjemah: Agus Setiadi, Editor: Hiang Marahimin, Cetakan I, Jakarta: P.T. Gaya Favorit Press. (1993)

26. Billore, S. dan H. Hägerdal. "The Indian Patola: import and consumerism in earlymodern Indonesia". Journal of Historical Research in Marketing 11 (3):271-294 (2019)

27. Mohan, U. "Historical and Contemporary Connections Between Indian and Indonesian Textiles: A Focus on Double-Ikat Patola". $7^{\text {th }}$ ASEAN Traditional Textile Symposium. India: Newyork University (2019)

28. Baral, B., B. Srikanth, Lija M.G., dan Smitha S. "Design Resource Patola Saree Weaving-Patan Double Ikat Style Sarees". http://www.dsource.in/resource/patola-sareeweaving-patan. Diakses tanggal 22 Maret 2018.

29. Cortesao, A. (Edit and Trans.). The Suma Oriental of Tomé Pires and The Book of Francisco Rodrigues, Second Series. No. LXXXIX. The Hakluyt Society (1944)

30. Reid, A. Asia Tenggara dalam Kurun Niaga 1450-1680, Jilid I: Tanah di Bawah Angin. Jakarta: Yayasan Pustaka Obor Indonesia (2011)

31. Pramudita, K. and R. Rosnawati. "Exploration of Javanese Culture Ethnomathematics Based on Geometry Perspective”. J. Physs.: Conf. Ser.1200 012002 (2019)

32. Zain, M. I. H. "Kontekstualisasi Hadis Larangan Menggambar dengan Desain Grafis". Riwayah: Jurnal Studi Hadis, Vol. 4, No. 1, hlm. 101-124 (2018)

33. Anonim. 2016. "Batik Pekalongan Jlamprang". September. Diakses tanggal 13 Januari 2021. http://menaracenter.org/wpcontent/uploads/2016/09/batik2Bpekalongan2Bjlmprang.jpgL. T. De Luca, Propulsion physics (EDP Sciences, Les Ulis, 2009)

34. G. Plancque, D. You, E. Blanchard, V. Mertens, C. Lamouroux, Role of chemistry in the phenomena occurring in nuclear power plants circuits, in Proceedings of the International Congress on Advances in Nuclear power Plants, ICAPP, 2-5 May 2011, Nice, France (2011) 